\title{
ICE Proceedings
}

In addition to Civil Engineering, ICE Proceedings includes 17 specialist journals. Papers and articles published in the most recent issues are listed here. Summaries of all these and other papers and articles published can be read free in the ICE Virtual Library at www.icevirtuallibrary.com/content/journals.

\section{Bridge Engineering}

169, No. BE1, March 2016, 1-78 Reliability analysis of a bridge network in Ireland

C. Hanley and V. Pakrashi

Composite cable-stayed bridges: state of the art

J. J. Oliveira Pedro and A. J. Reis

Contraction scour analysis at protruding bridge abutments

P. T. Ghazvinei, J. Ariffin, T. A. Mohammad,

S. A. Amini, M. A. Mir, S. Saheri and

S. Ansarimoghaddam

Structural analysis and design of a multispan network arch bridge

A. Pipinato

Seismic performance of a bridge with tall piers R. Kulkarni, S. Adhikary, Y. Singh and A. Sengupta

Civil Engineering Special
Issue
Humanitarian engineering
169, No. CE5, May 2016, 1-64
Re-engineering humanitarian

response - opportunity and

obligation

C. Lee and R. Potangaroa

Reducing rural isolation: a tale of two bridges

$\mathrm{H}$. Westerink and M. Alonso Barco

Sustainable roads for fragile states in Africa

M. Righi and N. Gardner

A low-cost vernacular improved housing

design

S. Kaminski, A. Lawrence, K. Coates and L. Foulkes

Protecting communities by remediating

polluted sites worldwide

D. Hanrahan, B. Ericson and J. Caravanos

The work of Engineers for Overseas

Development in humanitarian aid

I. Flower

Developing professional competencies for humanitarian engineers

B. Reed and E. Fereday

Managing safely in humanitarian projects

A. Brown

\section{Construction Materials \\ Recycled construction materials \\ 169, No. CM2, April 2016, 47-116 \\ An overview on recycling and \\ waste in construction}

J. Barritt

Recycling of demolition waste in

Merseyside

M. Soutsos and M. C. Fulton

Asbestos in recycled materials - modern risks

and future concerns

M. Fox
Recycled aggregates in structural concrete a Qatar case study

K. E.-G. Hassan, J. M. Reid and M. S. Al-Kuwari Using standard repair methods on recycled aggregate concrete

A. Badr

Use of crushed brick in reinforced earth

railway structures

S. Ellis, A. Goodwin, E. Laycock and C. Hurst

Waste glass aggregate for cementitious and polymer concrete

Ö. Andiç-Çakir, O. Üzüm, C. Yüksel and M. Sarikanat

\section{Energy}

169, No. EN2, May 2016, 47-90 Air conditioning systems for school buildings: a case study F. Ascione, L. Bellia, C. Mele and F. Minichiello

Energy harvesting on road pavements: state of the art

F. Duarte and A. Ferreira

\section{Engineering and} Computational Mechanics

169, No. EM1, March 2016, 1-41 Free vibration of FG Lévy plate resting on elastic foundations K. K. Pradhan and S. Chakraverty

Analysis of a thermosyphon using a

Mandelstam condition

F. Bahrami, M. Zarroug and P. Lundberg

\section{Engineering History and}

\section{Heritage}

169, No. EH2, May 2016, 55-108

Civil engineering heritage in

Spain: public protection strategies

R. Ruiz, L. Cruz, F. J. Rodriguez and

J. M. Coronado

Assessment of $\mathrm{U}$-type wrought iron railway bridges

L. Canning and M. M. Kashani

The gothic tower of Freiburg Minster,

Germany: analysis and repair

R. Barthel, J. Tutsch and J. Jordan

Civil engineering heritage: Country profile - Japan H. Isohata

Civil engineering heritage: Country profile -

Wales, UK

$\mathrm{K}$. Thomas and S. Jones

\section{Engineering Sustainability}

\section{Facilitating active travel}

169, No. ES2, April 2016, 47-84

Space for tricycles and bike

trailers: necessary provisions

G. Gaffga and C. Hagemeister
Estimating bicycle parking demand with limited data availability

P. C. Pfaffenbichler and T. Brezina

Can bicycle training for children increase active travel?

R. Johnson, M. Frearson and P. Hewson

Beyond walking and cycling: scoping

small-wheel modes

S. W. Lorimer and S. Marshall

\section{Forensic Engineering}

169, No. FE1, February 2016, 1-27

Deterioration assessment of an immersed-tube road tunnel in

Taiwan

Y.-C. Chou

Lessons learned from the Great East Japan

Earthquake

T. Tanikawa

\section{Geotechnical Engineering}

Innovation in deep foundation design and construction

169, No. GE2, April 2016, 95-223

The long-term behaviour of

retaining walls in Dublin

F. O'Leary, M. Long and M. Ryan

Primary firm secant pile concrete specification J. Gannon

Pile tests to justify higher adhesion factors in

London Clay

J. Martin, D. Budden and S. Norman

DSSI analysis of pile foundations for an oil

tank in Iraq

A. Kumar and D. Choudhury

Design of pile configuration for optimum raft performance

A. Maheetharan, A. Raveendiraraj, O. Qusous and

R. May

Mixed-in-place response of two carbonate

sands

P. Doherty, G. Spagnoli and D. Bellato

A hollow pile extended with a micropile:

tests and modelling

J. L. Justo, J. L. Arcos, E. Justo, R. Gil, M. Vázquez-

Boza, F. Martín and P Durand

Ultimate lateral capacity of timber poles embedded in clay

M. Pender and P. Rodgers

Behaviour of reinforced polyurethane resin micropiles

R. Valentino and D. Stevanoni

The boundary between deep foundations and ground improvement

B. Hamidi, F. Masse, J. Racinais and S. Varaksin Model tests of soil heave plug formation in

suction caisson

W. Guo, J. Chu and H. Kou 


\section{MONITOR:PROCEEDINGS}

\section{Ground Improvement}

169, No. GI2, May 2016, 79-156 Experimental study of dynamic compaction adjacent to a slope A. Vahidipour, A. Ghanbari and A. Hamidi

Radial consolidation clay behaviour under haversine cyclic load

S. S. Razouki

Behaviour of an embedded footing on geotextile-reinforced sand

M. Kazi, S. K. Shukla and D. Habibi

Mixing and compaction of fibre- and

lime-modified cohesive soil

C. Gelder and G. J. Fowmes

Ground surface settlements of sands densified with explosives

C. A. Vega-Posada and R. J. Finno

Behaviour of lignosulfonate-treated soil under cyclic loading

Q. Chen, B. Indraratna and C. Rujikiatkamjorn Field testing of permeation grouting using microfine cement

K. Hashimoto, S. Nishihara, S. Oji,

T. Kanazawa, S. Nishie, I. Seko, T. Hyodo

and Y. Tsukamoto

\section{Management}

Procurement and Law

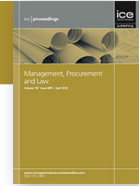

Compensation events in NEC3

contracts: case studies from

South Africa

S. Laryea

Late disputes and the NEC3 Engineering and

Construction Contract

I. Ndekugri

Social cohesion and interpersonal conflicts in projects

U. Ojiako, G. Manville, N. Zouk and M. Chipulu

Litigation following UK Water Resources Act section 110 appeal

M. Chapman

\section{Maritime Engineering}

169, No. MA1, March 2016, 1-45

Present-day use of an empirica wave prediction method

C. Lo Re, M. Cannarozzo and

G. B. Ferreri

Wave loading on rock lighthouses

A. Raby, G. N. Bullock, D. Banfi, Y. Rafiq and

F. Cali

Nature-based solutions: lessons from around the world

N. Pontee, S. Narayan, M. W. Beck and

A. H. Hosking

Engineering of an island-style breakwater system for the Fort Pierce marina

C. Cox and R. E. Czlapinski

Municipal Engineer
169, No. ME1, March 2016, 1-62
Using design-build system:
an interpretive structural model
B. Trigunarsyah and
A. A. D. Parami Dewi

Waynergy Vehicles: an innovative pavement energy harvest system

F. Duarte, J. P. Champalimaud and A. Ferreira

A new tram network for Bristol: a possible scenario?

H. A. Pollock Fraser, P. Christopher, C. Kennedy,

T. Webster, P. J. Vardanega and A. Johansson

Sewer risk management: reducing pollution

using minimum gradient and GIS

M. Baker

Dissolved oxygen model for a river with extreme fl ow variations

N. Ejaz, T. U Saeed, A. Ahmed and D. Khan

Building spatial cloud-based local government services

S. Bediroglu, V. Yildirim and R. Nisanci

\section{Structures and Buildings}

169. No SB4, April 2016, 235-312 Assessing reduction in concrete shear strength contribution

G. Arslan, S. Alacali and A. Sagiroglu

Modelling steel-strip-confined

reinforced-concrete columns

M. Rizwan, S. A. Khan, M. llyas and R.R. Hussain

Flexural performance of lightweight

reinforced-concrete slabs

R. Z. Al-Rousan

An examination of the crack control provision

in BS EN 1992-2

C. Arya

Effect of carbon fibre-reinforced polymers on structural behaviour of hollow-core slabs

L. A. Qureshi, M. Jawad, A. Elahi and A. Ajwad

Temporary support of five-storey building by column clamping

J. Rowe, J. McElhinney and N. Smith

Cement-stabilised rammed-earth square

column in compression

D. D. Tripura and K. D. Singh

\section{Transport}

169, No. TR2, April 2016, 63-121

Impacts of climate change on marginal nights for road salting

R. T. McSweeney, J. E. Tomlinson,

G. J. Darch, J. Parker and T. Holland

Hybrid model for prediction of real-time traffic flow

B. Yao, Z. Wang, M. Zhang, P. Hu and X. Yan

Driver injury severity analysis for two work

zone types

J. Weng, G. Du and L. Ma

Quality cost in bus operations based on

activity-based costing

A. García-Pastor, B. Guirao and M. E. López-Lambas

\section{Urban Design and Planning}

Latin America

169, No. DP2, April 2016, 45-115

Brazilian urban porosity: treat or threat?

I. M. Pessoa, T. Tasan-Kok and W. K. Altes

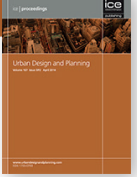

Urban land use pattern identification using variogram on image

D. L. Barros, M. A. Giannotti, A. P. C. Larocca and

J. A. Quintanilha

Improving urban thermal profile with trees and water features

É. Masiero and L. C. L. de Souza

Impacts of traffic calming interventions on urban vitality

O. Baptista Neto and H. M. Barbosa

A spatial multicriteria model for urban

accessibility mapping

D. S. Rodrigues, R. A. R. Ramos and M. G. S. Tobias Designing and modelling Havana's future bus rapid transit

J. P. Warren and A. Ortegon-Sanchez

\section{Waste and Resource}

Management

169, No. WR2, May 2016, 55-92

Aerobic treatment of leachate from municipal solid waste in Morocco

M. Abouri, S. Souabi, M. A. Bahlaoui,

F. Zouhir, M. Baudu, R. Moharram and A. Pala

Towards recycling and waste reduction in Mohammedia, Morocco

A. El Maguiri, I. Laila, B. Kissi and S. Souabi

Hazardous constituents of e-waste and predictions for India

S. Ahmed and R. M. Panwar

Recovery of lubricant base oils using ionic liquid processes

S. M. Grimes and F. Thompson

\section{Water Management}

Flood resilience

169, No. WM2, April 2016, 55-108

Methods of assessing flood

resilience of critical buildings

M. Escarameia, N. Walliman,

C. Zevenbergen and R. de Graaf

Liverpool integrated urban drainage:

a partnership approach

A. Parkes, G. Forrester, P. Spencer, L. Gilmore and G. Todd

Techniques for valuing adaptive capacity in flood risk management

R. Brisley, R. Wylde, R. Lamb, J. Cooper, P. Sayers and J. Hall

Enhancing urban flood resilience - a case study

for policy implementation

L. Nie

Sustainable drainage systems: helping people

live with water

G. Everett, J. Lamond, A. T. Morzillo, F. K. S. Chan

and A. M. Matsler

In addition to substantial discounts on ICE journal subscriptions, ICE members can also subscribe to the ICE Virtual Journal, offering access to 15 papers from any volume for $\mathbf{f 4 0}$. Visit www. icevirtuallibrary.com/info/icevirtualjournal for more information 